ROCZNIKI HUMANISTYCZNE

Tom LXVIII, zeszyt $10 \quad-\quad 2020$

DOI: http://dx.doi.org/10.18290/rh206810-7

SEBASTIAN PIOTROWSKI

KATARZYNA SADOWSKA-DOBROWOLSKA

\title{
TŁUMACZENIE PISEMNE NA JEZZYK POLSKI: O SPÓJNOŚCI TEKSTU DOCELOWEGO
}

\section{WPROWADZENIE}

Przygotowanie do zawodu tłumacza z założenia powinno obejmować co najmniej trzy obszary wiedzy i umiejętności ${ }^{1}$. Wynika to $z$ natury przekładu, który - jako proces wyrażenia sensu tekstu napisanego w języku źródłowym za pomocą struktur języka docelowego (Nida) - wymaga znajomości:

- języka źródłowego ${ }^{2}$, będącej gwarancją zrozumienia oryginalnego tekstu zgodnie $\mathrm{z}$ intencją autora;

- metodologii przekładu, tj. strategii, metod, technik itp. transferu sensu, stanowiących podstawę warsztatu tłumacza;

- języka docelowego, niezbędnej do właściwego wyrażenia sensu tekstu źródłowego i do poprawnego zredagowania tłumaczenia.

Wymienione elementy profilu zawodowego są równoważne, przy czym trzeci z nich odgrywa szczególną rolę, ponieważ decyduje o jakości końcowego efektu pracy tłumacza. Tymczasem teoria i dydaktyka przekładu zdają

Dr hab. Sebastian Piotrowski - Katolicki Uniwersytet Lubelski Jana Pawła II, Instytut Językoznawstwa, Katedra Kultur i Literatur Romańskich; e-mail: sepio@kul.pl. ORCID: https:// orcid.org/ 0000-0002-4871-5131

Dr Katarzyna SadowsKa-Dobrowolska - Uniwersytet Marii Curie-Skłodowskiej, Instytut Filologii Polskiej, Katedra Semantyki, Pragmatyki i Teorii Języka; e-mail: sadowska.dobrowolska@ gmail.com. ORCID: https://orcid.org/0000-0001-8627-6486

${ }^{1}$ Wymienione obszary wiedzy i umiejętności są tylko jednym z elementów składowych tzw. kompetencji tlumaczeniowej, prezentowanej $\mathrm{w}$ literaturze przedmiotu jako wieloaspektowe i wewnętrznie złożone zagadnienie (zob. Kelly; Piotrowska i in.; Dybiec-Gajer) i nie wyczerpują listy wymagań kompetencyjnych, stawianych przyszłym tłumaczom. Ze względu na ograniczenia edytorskie Autorzy zdecydowali się skupić na tych składnikach kompetencji, które wydają się podstawowe w przypadku redagowania tekstu.

${ }^{2}$ Mianem języka źródłowego określany będzie język obcy (tu: język francuski), język docelowy jest natomiast rozumiany jako język ojczysty (tu: język polski). 
się nie w pełni dostrzegać jego wagę. Znajomość języka ojczystego jest niejako zakładana a priori ${ }^{3}$, czego ilustracją mogą być opracowania poświęcone dydaktyce translacyjnej, skupiające się na kwestii znajomości języka obcego lub na klasyfikowaniu błędów w przekładach, pozbawione jednak refleksji na temat kompetencji w zakresie języka docelowego. Jest ona co prawda wymieniana $\mathrm{w}$ wielu pracach jako ważny składnik zawodowego profilu tłumacza, ale w programach studiów traduktologicznych jej rozwijanie wciąż zdaje się niedoceniane. Pojawiają się wprawdzie nieliczne wzmianki o konieczności rozszerzenia tych programów o przedmioty z zakresu kultury języka polskiego, stylistyki czy tekstologii, wciąż jednak są to głosy odosobnione ${ }^{4}$. Tymczasem praktyka pokazuje, że wysoka kompetencja $\mathrm{w}$ języku ojczystym (jako docelowym), polegająca na umiejętności poprawnego redagowania spójnego tekstu, z uwzględnieniem niuansów składniowych, leksykalnych (semantycznych) i stylistycznych, jest niezbędnym elementem profesjonalnego przygotowania do wykonywania zawodu tłumacza.

Celem niniejszego artykułu jest zasygnalizowanie problemów z zakresu tworzenia spójnego tekstu tłumaczenia $\mathrm{w}$ języku polskim, $\mathrm{z}$ jakimi borykają się studenci polonofoni ${ }^{5}$, oraz zwrócenie uwagi na konieczność rozwijania tej kompetencji w toku studiów. Ilustracją rozważań są wybrane przykłady błędnie zredagowanych tłumaczeń ${ }^{6}$, zaczerpnięte ze studenckich przekładów tekstu ekonomicznego pt. „Kraft veut briser le monopole de Nutella” (lefigaro.fr 20.02.2012).

Badacze zajmujący się problematyką translacji wiele uwagi poświęcają kwestiom typu źródła błędów, ich klasyfikacjom czy też kryteriom oceny tłumaczeń. Poprawność tekstu docelowego jest zwykle rozważana w kategoriach wierności w stosunku do oryginału (Karczewska; Hejwowski, Kognitywno-komunikacyjna i „Klasyfikacja”; Matulewska; Paprocka), co skutkuje ewaluacją efektów tłumaczenia, polegającą na zestawieniu przekładu

\footnotetext{
${ }^{3} \mathrm{~W}$ jednym $\mathrm{z}$ artykułów poświęconych problemom z przekładem Zofia Kozłowska pisze na ten temat tak: „Główną przyczyną błędów językowych (w tłumaczeniach z języka rosyjskiego) nie jest nieznajomość języka przekładu, który jest przecież językiem ojczystym, lecz interferencja” (Kozłowska 140).

${ }^{4}$ Kozłowska, w przytaczanym już artykule, wspomina o współpracy z polonistami w ramach formacji tłumaczeniowych. O konieczności kształcenia kompetencji tekstowej tłumaczy piszą też Wacław Cockiewicz i Małgorzata Brożyna-Reczko.

${ }^{5}$ Autorami przytoczonych w tekście thumaczeń są studenci 2. roku, odbywający studia II. stopnia na kierunku Filologia Romańska. Instytut, w którym przeprowadzono badanie, nie oferuje opcji traduktologicznej, tłumaczenia zaś zostały wykonane w ramach zajęć Tłumaczenia specjalistyczne, które są częścią obowiązkowej formacji ogólnej.

${ }^{6}$ Wszystkie thumaczenia podawane są w formie oryginalnej, bez jakichkolwiek modyfikacji.
} 
z tekstem źródłowym i porównywaniu ich pod kątem ewentualnych różnic i modyfikacji. W efekcie w centrum uwagi sytuowane są zwykle błędy w tłumaczeniu wynikające $\mathrm{z}$ niedostatecznej kompetencji w zakresie języka źródłowego lub będące skutkiem braków w wiedzy ogólnej tłumacza. Błędy językowe są wymieniane jako efekt interferencji, nieznajomości dziedziny czy też braku wrażliwości na obowiązujące konwencje. Jeśli jednak spojrzymy na tekst z perspektywy odbiorcy docelowego (tj. tak, jak będzie on ostatecznie funkcjonował), to okazuje się, że jego zrozumienie jest zaburzane przede wszystkim przez błędy w użyciu języka docelowego. Wydaje się zatem, że skupianie dydaktyki przekładu na procesie ekwiwalentyzacji (język obcy $\rightarrow$ język ojczysty) jest niewystarczające z punktu widzenia zawodowych realiów pracy tłumacza. Istotna jest także umiejętność spojrzenia na tekst docelowy jako na autonomiczną, konstrukcyjnie i semantycznie spójną całość.

\section{TEKST JAKO NIEZALEŻNA MAKROSTRUKTURA FORMALNO-SEMANTYCZNA}

Efektem końcowym pracy tłumacza jest tekst (ustny bądź pisany), czyli „ponadzdaniowa [...] jednostka językowa, makroznak samodzielny komunikacyjnie [...]" (Bartmiński i Niebrzegowska-Bartmińska 36), którego nadrzędnym zadaniem jest realizacja wybranych funkcji komunikacyjnych (Jakobson $)^{7}$. Jedną z kluczowych cech tak rozumianego tekstu jest jego spójność formalna (kohezja) i znaczeniowa (koherencja), realizująca się na wszystkich płaszczyznach organizacji tekstowej i będąca tym, co różni zbiór luźno zestawionych z sobą zdań od tekstu. Zgodnie z klasyczną już propozycją Marii Renaty Mayenowej spójność tekstu to „taka właściwość, która sprawia, że rozumiejący tekst odbiorca ujmuje go jako wypowiedź jednego nadawcy do jednego odbiorcy o jednym przedmiocie" (Mayenowa 252). Jedność nadawcy i jedność odbiorcy buduje korelacja wyrażeń deiktycznych, z kolei jedność tematyczną zapewnia tematyzacja treści, czyli dbałość o strukturę tematyczno-rematyczną wypowiedzi. Ponadto spójność referencjalną buduje izotopia, czyli „równoważność (ekwiwalencja) między kolejno następującymi wyrażeniami w tekście (stojącymi w niezbyt dużej odległości

\footnotetext{
${ }^{7} \mathrm{O}$ komunikacyjnej funkcji tekstu i potrzebie traktowania go jako całości pisała też Teresa Dobrzyńska: „funkcja komunikatywna tekstu - przysługująca mu w sposób całościowy - pociąga za sobą konieczność spojrzenia na tekst jako na jeden złożony znak” (Dobrzyńska 17).
} 
linearnej)" (Bartmiński i Niebrzegowska-Bartmińska 274). Poszczególne typy spójności są budowane ,punktowo” przy użyciu konkretnych środków językowych, spośród których do najważniejszych należą:

a) operatory treści, tj. „wyrażenia dotyczące poziomu przedmiotowego, tego, o czym się w tekście mówi, na ile to jest prawdziwe i wartościowe" (Bartmiński i Niebrzegowska-Bartmińska 192). Do tej grupy należą m.in.

- wyrażenia wyrażające stosunek treści zdania do rzeczywistości, np. naprawdę, oby, kiedy, jak itp. ${ }^{8}$;

- operatory uwydatniające wybrane elementy treści, np. znów, nawet, $a \dot{z}$ itp.;

b) operatory wewnątrztekstowe:

- wykładniki segmentacji tekstu, jego początku i końca, np. na poczatek, kończąc itp.

- operatory „sterujące tematem”, sygnalizujące rozczłonkowanie tematyczno-rematyczne wypowiedzi, np. przejdę do, jeśli chodzi o;

- sygnały dygresji, np. na marginesie; i wskaźniki lokalizacji tekstowej (czyli „wykładniki związków między fragmentami wypowiedzi"), np. najpierw, w tym miejscu itp.

- sygnały następstwa i porządku logicznego, np. po pierwsze; przede wszystkim itp.

- sygnały przytoczeń, czyli „wskaźniki intertekstowe”, np. jak powiedziat, odsytam do itp.

c) izotopia, np.

- derywat słowotwórczy od poprzednio użytego wyrażenia, np. Nestlé przejęto Gerbera w 2007 r. Przejęcie to byto wówczas jednym $z$ większych $w$ branży.

- pronominalizacja (zastąpienie pełnoznacznej nazwy zaimkiem), np. Clarins jest niewielka, rodzinna firma. Dlatego jest on na celowniku większych graczy.

- substytucje, np. nazwa pospolita za własną: Nutella pojawita sie na rynku w 1964 r. Od tamtej pory grono amatorów czekoladowego kremu wciąż rośnie.

d) „lokalne” mechanizmy spójności, m.in. konektory, np. i, ale; jeśli... to;

e) „globalne" mechanizmy spójności, m.in. stylowa i gatunkowa konwencja wypowiedzi, globalny temat oraz środki delimitujące (tj. tytuł, podział na akapity itd.).

\footnotetext{
${ }^{8}$ Podajemy za: Bartmiński i Niebrzegowska-Bartmińska 192-196.
} 
Spójność tekstu jest stopniowalna i wynika ze współgrania i współwystępowania różnych czynników tekstotwórczych. Jej budowanie może opierać się na różnych mechanizmach i różnych środkach językowych, w zależności od gatunku i funkcji redagowanej wypowiedzi. W przypadku tłumaczenia dodatkowym wyzwaniem jest to, że każdy język wypracowuje inne wzorce tekstowe, a w konsekwencji - odmienne mechanizmy budowania spójności (np. wymaga innej konstrukcji zdań). $Z$ tego względu kopiowanie struktury tekstu źródłowego jest obarczone ryzykiem błędu. Z tego samego powodu kształcenie w zakresie poprawnej redakcji tekstu wydaje się ważnym elementem dydaktyki translatorycznej.

\section{KOHEZJA I KOHERENCJA \\ A BŁĘDY W REDAGOWANIU SPÓJNEGO TEKSTU}

Spójność tekstu jest jego cechą globalną, będącą efektem sposobu formalno-semantycznej organizacji tekstu na wszystkich jego płaszczyznach: od syntaktycznej, poprzez semantyczną, stylistyczną, genologiczną i tekstową aż po pragmatyczną. Poniższa analiza ma na celu uchwycenie błędów tłumaczeniowych powodujących zaburzenia kohezji i koherencji tekstu docelowego, a mianowicie: brak konektorów wewnątrz- i międzyzdaniowych, brak budowania izotopii, brak sygnalizowania zmiany tematu, kalkowanie oryginalnej struktury tematyczno-rematycznej.

Brak konektorów wewnątrz- $i$ międzyzdaniowych

\begin{tabular}{|c|c|}
\hline Tekst źródłowy & Tekst docelowy (tłumaczenie) \\
\hline \multirow[t]{2}{*}{$\begin{array}{l}\text { Le groupe américain lance une pâte à tartiner } \\
\text { au chocolat. Un segment où l'italien Ferrero } \\
\text { détient } 84 \% \text { de marché. }\end{array}$} & $\begin{array}{l}\text { [1] Amerykańska grupa wprowadza na rynek serek z cze- } \\
\text { koladą do smarowania pieczywa. Dział, w którym włoska } \\
\text { firma Ferrero posiada } 84 \% \text { sprzedaży na rynku. }\end{array}$ \\
\hline & $\begin{array}{l}\text { [2] Amerykańska grupa wprowadza na rynek czekoladowy } \\
\text { krem do smarowania pieczywa. Segment, w którym włoskie } \\
\text { Ferrero posiada } 84 \% \text { rynku. }\end{array}$ \\
\hline $\begin{array}{l}\text { Avec ce produit à base de fromage, Kraft ne } \\
\text { veut pas jouer les clones de Nutella. "Nous } \\
\text { avons quelque chose de très complémentaire à } \\
\text { apporter», promet Fabien Razac. II revendique }\end{array}$ & $\begin{array}{l}\text { [3] Tym produktem na bazie sera, Kraft nie chce powielać } \\
\text { wyrobów Nutelli. "Zamierzamy uzupełnić, istniejącą już } \\
\text { gamę produktów" obiecuje Fabien Razac. Powołuje się on } \\
\text { zarówno na smak, jak i na wartość odżywczą produktu }\end{array}$ \\
\hline
\end{tabular}


à la fois la gourmandise et le profil nutritionnel du produit $(13,5 \%$ de matière grasse, 305 calories pour $100 \mathrm{~g}$, contre 530 pour Nutella). Un terrain sensible pour son concurrent, régulièrement objet d'attaques de consommateurs.
(13,5\% tłuszczu, 305 kalorii na 100g, w przeciwieństwie do 530 w przypadku Nutelli). Delikatna kwestia dla jego konkurenta, przedmiot regularnych ataków konsumentów.

Tłumaczenia sprawiają wrażenie luźno zestawionych zdań, między którymi trudno jest doszukać się związku strukturalno-semantycznego. Z tego względu nie przypominają tekstu, a ich lektura i zrozumienie globalnego sensu jest utrudniona. Zadaniem odbiorcy staje się bowiem nie tylko interpretacja, ale też uzupełnienie czytanych zdań o niezbędne konektory logiczne.

\section{Brak budowania izotopii tekstu}

\begin{tabular}{|c|c|}
\hline Tekst źródłowy & Tekst docelowy \\
\hline $\begin{array}{l}\text { Le groupe américain lance une pâte à } \\
\text { tartiner au chocolat. Un segment où l'italien } \\
\text { Ferrero détient } 84 \% \text { de marché. }\end{array}$ & $\begin{array}{l}\text { [1] Amerykańska grupa Kraft wprowadziła na rynek nowy } \\
\text { krem czekoladowy. Tworząc konkurencję dla włoskiego } \\
\text { producenta Ferrero, lidera cukiernictwa (zajmuje } 84 \% \\
\text { rynku). }\end{array}$ \\
\hline $\begin{array}{l}\text { Kraft est bien décidé à briser le quasi-mono- } \\
\text { pole de Nutella. }\end{array}$ & $\begin{array}{l}\text { Firma Kraft zdecydowała się położyć kres częściowemu } \\
\text { monopolowi Nutelli }\end{array}$ \\
\hline $\begin{array}{l}\text { Avec ce produit à base de fromage, Kraft ne } \\
\text { veut pas jouer les clones de Nutella. "Nous } \\
\text { avons quelque chose de très complémentaire à } \\
\text { apporter ", promet Fabien Razac. II reven- } \\
\text { dique à la fois la gourmandise et le profil } \\
\text { nutritionnel du produit ( } 13,5 \% \text { de matière } \\
\text { grasse, } 305 \text { calories pour } 100 \mathrm{~g} \text {, contre } 530 \\
\text { pour Nutella). Un terrain sensible pour son } \\
\text { concurrent, régulièrement objet d'attaques } \\
\text { de consommateurs. }\end{array}$ & $\begin{array}{l}\text { [2] Kraft, ze swoim nowym produktem na bazie sera, nie } \\
\text { ma zamiaru tworzyć klonu Nutelli. „Mamy do zaoferowania } \\
\text { coś ciekawszego" zapewnia Fabien Razac. Przywołuje on } \\
\text { zarówno wspaniały smak produktu, jak i jego wartości } \\
\text { odżywcze (13,5\% tłuszczu, } 305 \text { kalorii na } 100 \mathrm{~g}, \text { w po- } \\
\text { równaniu z Nutellą zawierającą aż } 530 \text { kcal na } 100 \mathrm{~g} \\
\text { produktu). Delikatny temat dla Nutelli, krytykowanej za } \\
\text { swój skład przez konsumentów. }\end{array}$ \\
\hline
\end{tabular}

W obu przykładach tłumaczenia zawierają powtórzenia tego samego elementu (Kraft, Nutella) ze szkodą dla warstwy stylistycznej tekstu docelowego. Powtórzenia są zarówno wynikiem kopiowania struktur oryginalnych (kalki), jak i nadmiernego objaśniania tłumaczonego tekstu, bez zwracania uwagi na możliwość wykorzystania innych mechanizmów budowania jego izotopii. 


\section{Brak sygnalizowania zmiany tematu}

\begin{tabular}{|c|c|}
\hline Tekst źródłowy & Tekst docelowy \\
\hline $\begin{array}{l}\text { Baptisée "Philadelphia avec Milka », elle sera } \\
\text { vendue au rayon frais, aux côtés de St. Môret, } \\
\text { Boursin et Kiri, alors que Nutella est implantée } \\
\text { à côté des miels et confitures. "On retrouve } \\
\text { l'onctuosité, la fraîcheur et la légèreté de Phila- } \\
\text { delphia ainsi que l'aspect chocolaté de Milka ", } \\
\text { assure Fabien Razac, directeur marketing de } \\
\text { Philadelphia en France. }\end{array}$ & $\begin{array}{l}\text { [1] Produkt nazwany „Philadelphia z Milką”, będzie sprze- } \\
\text { dawany w regałach chłodniczych, obok St. Môret, Boursin i Kiri, } \\
\text { podczas gdy Nutella znajduje się obok miodów i dżemów. } \\
\text { "Znajdziemy kremową konsystencję, świeżóś́ i lekkoś́ } \\
\text { w Philadelphii oraz czekoladowy smak Milki” - zapewnia } \\
\text { Fabien Razac, dyrektor marketingu Philadelphii we Francji. }\end{array}$ \\
\hline
\end{tabular}

W powyższym przykładzie pojawia się nieumiejętne przejście od tematu zdania pierwszego do właściwości opisywanego produktu: użycie czasownika znajdować w kontekście wcześniej opisywanego usytuowania go w hipermarketach wprowadza odbiorcę w błąd, sugerując kontynuację tego tematu.

Kopiowanie oryginalnej struktury tematyczno-rematycznej

\begin{tabular}{|l|l|}
\hline \multicolumn{1}{|c|}{ Tekst źródłowy } & \multicolumn{1}{c|}{ Tekst docelowy } \\
\hline $\begin{array}{l}\text { Le 15 mars, le géant mondial de l'agroalimen- } \\
\text { taire (LU, Oréo, Milka, Trident...) lance dans les } \\
\text { grandes surfaces de I'Hexagone sa propre pâte à } \\
\text { tartiner au chocolat. }\end{array}$ & $\begin{array}{l}\text { [1] 15 marca, światowy potentat przemysłu spożywczego (tj. } \\
\text { LU, Oreo, Milka, Trident...) wprowadza na francuski rynek } \\
\text { własną wersję kremu czekoladowego. }\end{array}$ \\
\hline $\begin{array}{l}\text { Avec ce produit à base de fromage, Kraft ne veut } \\
\text { pas jouer les clones de Nutella. }\end{array}$ & $\begin{array}{l}\text { [2] Z produktem na bazie sera, Kraft chce odróżnić się od } \\
\text { Nutelli. }\end{array}$ \\
\hline $\begin{array}{l}\text { Un terrain sensible pour son concurrent, régu- } \\
\text { lièrement objet d'attaques de consommateurs. }\end{array}$ & $\begin{array}{l}\text { [3] Delikatna kwestia dla jego konkurenta, przedmiot regu- } \\
\text { larnych ataków konsumentów. }\end{array}$ \\
\hline
\end{tabular}

Zachowanie oryginalnej struktury składniowej w zdaniach docelowych sprawiło, że informacje zawarte w przytoczonych thumaczeniach stały się niejasne. Co więcej, nieprawidłowe zastosowanie znaków interpunkcyjnych (zdanie 1. i 2.) i operatorów treści (zdanie 1.) zmieniło sens tekstu źródłowego. 


\section{REMEDIUM: ZAJĘCIA TEORETYCZNO-PRAKTYCZNE Z ZAKRESU SPÓJNOŚCI TEKSTU}

Na podstawie przeanalizowanych tłumaczeń można stwierdzić, że zdecydowana większość popełnionych błędów i usterek stylistycznych ma swoje źródło nie w trudnościach ze zrozumieniem oryginalnego tekstu bądź w braku wiedzy ogólnej, ale przede wszystkim w nieumiejętności prawidłowego zredagowania tekstu docelowego. Mając na uwadze poprawę jakości studenckich tłumaczeń, przeprowadzono zajęcia teoretyczne, poświęcone zagadnieniu spójności tekstu. Ich celem było uświadomienie studentom sposobu funkcjonowania przekładu (jako kompletnej i samodzielnej makrostruktury) oraz zapoznanie ich z regułami budowania spójności tekstu w języku polskim. W pierwszej kolejności zostały omówione wcześniejsze tłumaczenia studentów. Ich analiza odeszła od tradycyjnego skupiania się na błędach rzeczowych (niepełna kompetencja studentów w języku źródłowym) i nie polegała na porównywaniu tekstu wyjściowego do tekstu docelowego. Punktem wyjścia był tekst tłumaczenia i uchybienia językowe powodujące jego „nieczytelność". Brak oryginalnego tekstu jako punktu odniesienia skłonił studentów do spojrzenia na tekst docelowy jako na samodzielny byt, którego zadaniem jest przekazanie informacji. To z kolei zmieniło kryteria oceny tekstu i pokazało studentom, że problemem w ich przekładach okazało się przede wszystkim zachowanie właściwego toku logicznego, jednolitego stylu i rejestru językowego. Kolejnym krokiem były zajęcia teoretyczne, poświęcone zaznajomieniu studentów z teorią spójności tekstu i przedstawieniu im mechanizmów budowania kohezji i koherencji. W celu utrwalenia wiedzy przeprowadzono ćwiczenia dotyczące redagowania spójnego tekstu w języku polskim.

\section{EFEKTY: ZASTOSOWANIE NOWO ZDOBYTEJ WIEDZY W TŁUMACZENIACH KONTROLNYCH}

Na podstawie tłumaczeń przygotowanych bezpośrednio po zajęciach teoretycznych można stwierdzić, że studenci dostrzegli potrzebę „spajania” poszczególnych zdań i dbania o ponadzdaniową strukturę przekładu: w tekstach docelowych pojawiło się znacznie więcej konektorów nawiązania wewnątrz- i międzyzdaniowego. Poniższa tabela przedstawia wykorzystane przez studentów wykładniki kohezji i koherencji ${ }^{9}$ :

\footnotetext{
${ }^{9} \mathrm{~W}$ trosce o przejrzystość tabeli w tej kolumnie wymieniany jest jedynie główny mechanizm budowania spójności, zastosowany w danym fragmencie tłumaczenia.
} 


\begin{tabular}{|c|c|c|}
\hline Tekst źródłowy & Tekst docelowy & Mechanizm budowania spójności \\
\hline \multirow[t]{3}{*}{$\begin{array}{l}\text { S'il cible en priorité le goûter } \\
\text { des enfants, Kraft entend aussi } \\
\text { séduire les parents, au petit } \\
\text { déjeuner mais aussi dans la } \\
\text { cuisine, pour confectionner des } \\
\text { gâteaux. }\end{array}$} & $\begin{array}{l}\text { [1] Stawiając jako priorytet zadowolenie } \\
\text { dzieci, firma Kraft chce również przyciąg- } \\
\text { nąć uwagę ich rodziców, proponując pro- } \\
\text { dukt zarówno na śniadanie, jak i i do robie- } \\
\text { nia ciasta. }\end{array}$ & $\begin{array}{l}\text { Zmiana struktury składniowej } \\
\text { zdania. }\end{array}$ \\
\hline & $\begin{array}{l}\text { [2] Kraft nie chce się skupiać tylko na } \\
\text { dzieciach, pragnie także pozyskać rodzi- } \\
\text { ców, dostarczając produkt nie tylko na } \\
\text { śniadanie, ale również do innych potraw, } \\
\text { między innymi ciast. }\end{array}$ & $\begin{array}{l}\text { Zmiana struktury tematyczno- } \\
\text { rematycznej zdania. }\end{array}$ \\
\hline & $\begin{array}{l}\text { [3] Firma Kraft skupia się nie tylko na } \\
\text { przekąskach dla dzieci. Jej grupą docelową } \\
\text { są również dorośli, gdyż nowy serek do sma- } \\
\text { rowania jest produktem zarówno śniada- } \\
\text { niowym, jak i do pieczenia ciast. }\end{array}$ & $\begin{array}{l}\text { Zmiana segmentacji treści } \\
\text { (rozbicie oryginalnej struktury } \\
\text { składniowej). }\end{array}$ \\
\hline \multirow[t]{2}{*}{$\begin{array}{l}\text { Le recours à ses deux marques } \\
\text { vedettes - la familiale Milka } \\
\text { et Philadelphia, plus adulte - } \\
\text { lui permet d'élargir sa cible. }\end{array}$} & $\begin{array}{l}\text { [4] Kraft korzysta z dwóch flagowych ma- } \\
\text { rek - rodzinnej Milki i starszej Philadelphii. } \\
\text { Dzięki temu poszerzy on swoją grupę doce- } \\
\text { lową. }\end{array}$ & $\begin{array}{l}\text { Zmiana segmentacji treści } \\
\text { (rozbicie oryginalnej struktury } \\
\text { składniowej). }\end{array}$ \\
\hline & $\begin{array}{l}\text { [5] W związku z tym, wykorzystanie dwóch } \\
\text { wiodących marek tj. Milka i Philadelphia, } \\
\text { pozwoli na poszerzenie grupy docelowej. } \\
\text { [6] To właśnie dzięki korzystaniu z dwóch } \\
\text { flagowych marek, jakimi są Milka i Phila- } \\
\text { delphia, cel firmy staje się możliwy do osiag- } \\
\text { nięcia. }\end{array}$ & $\begin{array}{l}\text { Wprowadzenie nawiązań } \\
\text { międzyzdaniowych. } \\
\text { Zmiana segmentacji treści. }\end{array}$ \\
\hline \multirow[t]{3}{*}{ Le pari est pourtant risqué. } & [7] Taki zabieg może być jednak ryzykowny. & \multirow{2}{*}{$\begin{array}{l}\text { Wprowadzenie zaimków } \\
\text { wskazujących w funkcji nawiązań } \\
\text { międzyzdaniowych. }\end{array}$} \\
\hline & $\begin{array}{l}\text { [8] To założenie niesie jednak za sobą } \\
\text { pewne ryzyko. }\end{array}$ & \\
\hline & $\begin{array}{l}\text { [9] Założenia te nie są jednak pewne, bo } \\
\text { o ile Milka jest dobrze znana Francuzom, } \\
\underline{\text { otyle serek śmietankowy Philadelphia, }}\end{array}$ & $\begin{array}{l}\text { Zmiana segmentacji treści } \\
\text { (połączenie dwóch zdań). }\end{array}$ \\
\hline
\end{tabular}




\begin{tabular}{|c|c|c|}
\hline \multirow[b]{2}{*}{$\begin{array}{l}\text { Si Milka est très connu des } \\
\text { Français, le fromage à tartiner } \\
\text { Philadelphia, lancé en grande } \\
\text { pompe il y a un an, fait encore } \\
\text { figure de nouveau venu dans } \\
\text { I'Hexagone malgré ses bons } \\
\text { scores ( } 3 \text { millions de foyers } \\
\text { l'ont testé). }\end{array}$} & $\begin{array}{l}\text { mimo swojego mocnego wejścia na rynek } \\
\text { i dobrych wyników sprzedażowych (przete- } \\
\text { stowany został przez } 3 \text { miliony rodzin), } \\
\text { wciąż uznawany jest we Francji za nowość. }\end{array}$ & \\
\hline & $\begin{array}{l}\text { [10] Po pierwsze Milka jest dobrze znana } \\
\text { Francuzom, natomiast ser Philadelphia, } \\
\text { który wszedł na rynek z wielką pompą rok } \\
\text { temu, wciąż jest nowicjuszem we Francji } \\
\text { pomimo dobrych wyników (zweryfikowano } \\
3 \text { miliony gospodarstw domowych). } \\
\text { [11] Po drugie konsument może również } \\
\text { czuć się zdezorientowany odnajdując sło- } \\
\text { dycz w dziale z nabiałem. }\end{array}$ & \multirow[t]{2}{*}{$\begin{array}{l}\text { Wprowadzanie konektorów } \\
\text { logicznych, budujących spójność } \\
\text { międzyzdaniową. }\end{array}$} \\
\hline \multirow{2}{*}{$\begin{array}{l}\text { Le consommateur risque par } \\
\text { ailleurs d'être dérouté de } \\
\text { retrouver une référence sucrée } \\
\text { au rayon fromage. }\end{array}$} & $\begin{array}{l}\text { [12] Co więcej, konsument może być zde- } \\
\text { zorientowany szukając słodkości, które znaj- } \\
\text { dują się na półkach obok serów. }\end{array}$ & \\
\hline & $\begin{array}{l}\text { [13] Inna niedogodnościq może okazać się } \\
\text { dezorientacja konsumenta, który chcąc } \\
\text { kupić słodki produkt musi udać się do } \\
\text { działu z serami. }\end{array}$ & $\begin{array}{l}\text { Wprowadzenie leksykalnego na- } \\
\text { wiązania międzyzdaniowego. }\end{array}$ \\
\hline \multirow{2}{*}{$\begin{array}{l}\text { Fort du succès en Allemagne } \\
\text { de sa pâte à tartiner au cho- } \\
\text { colat, où le Philadelphia clas- } \\
\text { sique est installé depuis long- } \\
\text { temps, Kraft est ambitieux en } \\
\text { France, son deuxième marché } \\
\text { derrière les États-Unis. }\end{array}$} & $\begin{array}{l}\text { [14] Ten krem czekoladowy odniósł duży } \\
\text { sukces w Niemczech, gdzie klasyczna Fila- } \\
\text { delfia jest na półkach od dawna. We Francji } \\
\text { zajmuje drugie miejsce na rynku, zaraz po } \\
\text { Stanach Zjednoczonych. }\end{array}$ & $\begin{array}{l}\text { Zmiana segmentacji treści } \\
\text { (rozbicie oryginalnej struktury } \\
\text { składniowej). }\end{array}$ \\
\hline & $\begin{array}{l}\text { [15] Francja jest drugim, zaraz po Stanach } \\
\text { Zjednoczonych, rynkiem zbytu dla firmy } \\
\text { Kraft. Interes w podboju serc francuskich } \\
\text { konsumentów oraz sukces w Niemczech } \\
\text { (gdzie Philadelphia jest znana już od dłuż- } \\
\text { szego czasu), sprawiły, że producent serka } \\
\text { nie traci swoich ambicji. }\end{array}$ & $\begin{array}{l}\text { Zmiana segmentacji treści. } \\
\text { Zmiana struktury tematyczno- } \\
\text { rematycznej zdań. }\end{array}$ \\
\hline
\end{tabular}




\begin{tabular}{|c|c|c|}
\hline $\begin{array}{l}\text { "Nous allons de nouveau bous- } \\
\text { culer les codes du marché, es- } \\
\text { time Fabien Razac. }\end{array}$ & $\begin{array}{l}\text { [16] Jak szacuje Fabian Razac, „Zamie- } \\
\text { rzamy ponownie zawojować rynek. }\end{array}$ & $\begin{array}{l}\text { Zmiana struktury tematyczno- } \\
\text { rematycznej zdania (zmiana } \\
\text { szyku). }\end{array}$ \\
\hline & $\begin{array}{l}\text { [17] „Zamierzamy na nowo wstrząsnąć } \\
\text { rynkiem, zapowiada się obiecująca przy- } \\
\underline{\text { szłość dla Philadelphii z Milką. }}\end{array}$ & $\begin{array}{l}\text { Zmiana segmentacji treści } \\
\text { (połączenie dwóch zdań). }\end{array}$ \\
\hline $\begin{array}{l}\text { Philadelphia avec Milka est pro- } \\
\text { mis à un bel avenir en France. }\end{array}$ & $\begin{array}{l}\text { [18] Przyszłość serka Philadelphia z Milkq } \\
\text { we Francji zapowiada się dobrze. }\end{array}$ & $\begin{array}{l}\text { Zmiana struktury tematyczno- } \\
\text { rematycznej zdania. }\end{array}$ \\
\hline $\begin{array}{l}\text { Nous aimerions séduire } 3 \text { mil- } \\
\text { lions de foyers en deux ans». }\end{array}$ & $\begin{array}{l}\text { [19] We Francji Filadelfia i Milka ma wspa- } \\
\text { niałą przyszłość przed sobą, chcemy do sie- } \\
\text { bie przekonać } 3 \text { miliony rodzin w ciągu } \\
\text { dwóch lat. }\end{array}$ & $\begin{array}{l}\text { Zmiana segmentacji treści } \\
\text { (połączenie dwóch zdań). }\end{array}$ \\
\hline
\end{tabular}

Prezentowane tłumaczenia cechuje przede wszystkim odejście od formalnej struktury oryginału i próba redagowania tekstu realizującego zasady spójności obowiązujące w języku docelowym. W konsekwencji tłumaczenia przestały być składniowo-leksykalnymi kalkami i nabrały cech autonomicznych tekstów, w których pojawiły się następujące wykładniki kohezji i koherencji:

- zmiana segmentacji treści, czyli odmienny podział warstwy informacyjnej tekstu na zdania i wynikające $\mathrm{z}$ niego odejście od struktury składniowej tekstu źródłowego;

- zmiana struktury tematyczno-rematycznej zdań, tj. modulowanie treści podporządkowane strukturze tekstu docelowego, a nie źródłowego;

- wprowadzanie nawiązań międzyzdaniowych i konektorów logicznych budujących spójność wewnątrz- i międzyzdaniową;

- wprowadzanie leksykalnych nawiązań, nieobecnych w tekście źródłowym, ale koniecznych z punktu widzenia spójności tłumaczenia;

- wprowadzanie zmian w obrębie ciągów izotopicznych.

Jednocześnie w wielu przypadkach wskazane mechanizmy spójności tekstowej zostały zastosowane niepoprawnie, co pokazuje, że umiejętność jej budowania nie została $\mathrm{w}$ pełni wypracowana. Te tłumaczenia odzwierciedlają naturalny proces uczenia się, w którym pierwszym etapem jest niepełna kompetencja: próba aplikacji nowo zdobytej wiedzy, ale jeszcze z licznymi potknięciami, nadużyciami. Można przyjąć, że na tym etapie wiedza teo- 
retyczna została przyswojona, ale jej zastosowanie wymaga dalszych ćwiczeń, co z kolei sugeruje, że rozwijanie kompetencji w języku docelowym wymaga czasu i powinno przebiegać w formie cyklicznie odbywanych zajęć.

Efektem kolejnych prób tłumaczeń są teksty polskie wyraźnie tworzone w oderwaniu od struktury składniowej i spójnościowej tekstu źródłowego. Studenci zaczęli zwracać uwagę na czytelność i poprawność tekstu docelowego, funkcjonującego samodzielnie, tj. bez wersji źródłowej. Przeniesienie akcentów uwagi z obszaru relacji tekst źródlowy - tekst docelowy, a więc ekwiwalencji strukturalno-leksykalnej, na obszar finalnego odbioru pozwolił studentom zaobserwować, jak tekst będzie funkcjonował docelowo, oraz uświadomił im, jak ważna jest kwestia poprawnego konstruowania tekstu w języku ojczystym.

\section{WNIOSKI}

Postrzeganie tłumaczenia jako procesu tworzenia autonomicznego, kompletnego pod względem formalnym i semantycznym tekstu modyfikuje hierarchię ważności kompetencji rozwijanych w procesie nauczania przekładu. Powyższy artykuł zwraca uwagę na problemy z redakcją poprawnych, zrozumiałych i przejrzystych tekstów tłumaczenia, wynikające w większości przypadków z niewystarczającej kompetencji w zakresie tworzenia tekstu w języku polskim. Bez wiedzy ogólnej z zakresu tekstologii oraz solidnego przygotowania teoretyczno-praktycznego z zakresu współczesnego języka polskiego, stylistyki i kultury języka studenci nie są w stanie skutecznie rozwijać warsztatu tłumaczeniowego. Opisany w artykule cykl zajęć poświęconych zagadnieniu spójności tekstu docelowego pokazał efekty włączenia formacji polonistycznej do programu nauczania przyszłych tłumaczy. Przyjęcie perspektywy tekstu docelowego i jego odbioru pozwoliło uświadomić studentom, w jaki sposób funkcjonuje tłumaczenie i znacząco podnieść jakość wykonywanych przekładów, co pokazuje słuszność podjętych kroków dydaktycznych i pozwala przypuszczać, że formacja polonistyczna powinna stanowić obowiązkowy blok zajęć w programach dydaktyki przekładu. 


\section{BIBLIOGRAFIA}

Bartmiński, Jerzy, i Stanisława Niebrzegowska-Bartmińska. Tekstologia. Wydawnictwo Naukowe PWN, 2009.

Cockiewicz, Wacław, i Małgorzata Brożyna-Reczko. „Plan (de)kompozycyjny jako narzędzie analizy tekstu”. Problemy wspótczesnej glottodydaktyki i nauczania przekładu, red. Joanna Mampe, Jolanta Hinc i Adam Jarosz, Wydawnictwo Uniwersytetu Gdańskiego, 2017, ss. 225-244.

Daneš, František. „Semantyczna i tematyczna struktura zdania i tekstu”. Tekst i język. Problemy semantyczne, red. Renata Mayenowa, Ossolineum. Wydawnictwo PAN, 1974, ss. 23-40.

Dobrzyńska, Teresa. Tekst. Próba syntezy. Wydawnictwo IBL, 1993.

Dybiec-Gajer, Joanna. Zmierzyć przekład? Z metodologii oceniania $w$ dydaktyce przekładu pisemnego. Universitas, 2013.

Hejwowski, Krzysztof. Kognitywno-komunikacyjna teoria przekładu. Wydawnictwo Naukowe PWN, 2004.

- „Klasyfikacja błędów thumaczeniowych - teoria i praktyka”. Jakość i ocena tlumaczenia, red. Jerzy Tomaszczyk, Wydawnictwo Academia, 2009, ss. 141-161.

Jakobson, Roman. „Poetyka w świetle językoznawstwa”. Tłum. Krystyna Pomorska, Pamiętnik Literacki, vol. 51/2, 1960, ss. 431-473.

Karczewska, Dorota. „O błędach w tłumaczeniu”. Język rodzimy a język obcy. Komunikacja, przektad, dydaktyka, red. Andrzej Kopczyński i Urszula Zaliwska-Okrutna, Wydawnictwa Uniwersytetu Warszawskiego, 2002, ss. 129-135.

Kelly, Dorothy. A Handbook for Translator Trainers. St. Jerome Pub., 2005.

Kozłowska, Zofia. „O błędach językowych w tekstach polskich przekładów”. Język rodzimy a język obcy. Komunikacja, przeklad, dydaktyka, red. Andrzej Kopczyński, i Urszula ZaliwskaOkrutna, Wydawnictwa Uniwersytetu Warszawskiego, 2002, ss. 137-147.

Matulewska, Aleksandra. „Horrory thumaczeniowe czy tłumaczenia z piekła rodem? Czyli kilka słów o efektywności komunikacji interlingwalnej”. Scripta Neophilologica Posnaniensia, vol. 14, 2014, ss. 101-118.

Mayenowa, Maria Renata. Poetyka teoretyczna. Zagadnienia języka. wyd. 2, Ossolineum, 1979.

Nida, Eugene. Toward a Science of Translating. E.J. Brill, 1964.

Paprocka, Natalia. „Les erreurs relatives engendrées par les éléments culturels dans les traductions de textes pragmatiques français réalisées par des étudiants polonais". Romanica Wratislaviensia, vol. 52, 2005, ss. 63-76.

Piotrowska, Maria, Artur Czesak, Aleksander Gomola i Sergiy Tyupa, redaktorzy, Kompetencje ttumacza. Tom dedykowany Profesor dr hab. Elżbiecie Tabakowskiej, Tertium, 2012.

\section{TŁUMACZENIE PISEMNE NA JEZZYK POLSKI: O SPÓJNOŚCI TEKSTU DOCELOWEGO}

\section{Streszczenie}

Celem niniejszego artykułu jest przede wszystkim pokazanie problemów z zakresu poprawnego tworzenia spójnego tekstu tłumaczenia w języku polskim, z jakimi borykają się studenci polonofoni, a także zwrócenie uwagi na konieczność rozwijania tej kompetencji w toku studiów. 
Praktyka tłumaczeniowa pokazuje, że wysoka kompetencja w języku ojczystym (jako docelowym), polegająca na znajomości reguł tworzenia spójnego tekstu, z uwzględnieniem niuansów składniowych, leksykalnych (semantycznych) i stylistycznych, jest warunkiem sine qua non odniesienia zawodowego sukcesu. Podstawą przedstawionych w artykule analiz jest korpus prac tłumaczeniowych studentów polonofonów odbywających studia magisterskie na kierunku filologia romańska.

Słowa kluczowe: tłumaczenie pisemne; spójność tekstu; język źródłowy; język docelowy.

\section{TRANSLATING INTO POLISH: ON TARGET TEXT COHESION}

\section{S u m m a r y}

The purpose of this article is, above all, to draw attention to some of the problems which many Polish students face in the area of making a coherent translation of a foreign-language text into Polish. Additionally, the need to develop this competence during university studies will be discussed. Translation practice shows that high competence in one's native language (as the target language), consisting of the ability to create a coherent text, taking into account syntactic, lexical (semantic) and stylistic nuances, is a sine qua non for professional success. The object of the analyses presented in this article is a body of texts translated by Polish students who are studying for a master's degree in romance languages.

Key words: written translation; text cohesion; source language; target language. 